Katarzyna Wrońska*

ORCID: 0000-0001-6617-4415

Kraków

\title{
Wychowanie a wolność. Próba wglądu w myślenie pedagogiczne Józefa Tischnera
}

Nie jest łatwo mierzyć się z zadaniem odczytania myśli pedagogicznej Józefa Tischnera. Twórczość tego filozofa jest bardzo rozległa i tylko w niektórych miejscach dotyka bezpośrednio spraw wychowania i nauczania. Jest już jednak kilka większych studiów poświęconych rozumieniu i interpretowaniu pedagogicznych poglądów Tischnera $\mathrm{w}$ powiązaniu $\mathrm{z}$ jego filozofią ${ }^{1}$ bądź wprost z niej wywiedzionych ${ }^{2}$. Zadanie jest więc wykonalne. Propozycja, by powiązać jego myśl pedagogiczną z tematyką pokonywania drogi od totalitaryzmu do wolności, jest dogodną okazją, by zabrać głos w dyskusji, dołączając do grona badaczy zainteresowanych myślą Tischnera. Pisząc ten tekst z perspektywy pedagogiki filozoficznej, autorka stawia przed sobą zadanie wydobycia i odczytania ze źródłowych tekstów i wypowiedzi Tischnera - jako filozofa wolności - znaczeń i sensu, jakie nadaje on wychowaniu i nauczaniu. Cel tej pracy jest podwójny. Pierwszy z nich wiąże się z zainte-

* Dr hab. Katarzyna Wrońska jest kierownikiem Zakładu Pedagogiki Ogólnej i Filozoficznej w Instytucie Pedagogiki Uniwersytetu Jagiellońskiego w Krakowie. Adres: Instytut Pedagogiki UJ, ul. Batorego 12,31-135 Kraków; e-mail: katarzyna.wronska@uj.edu.pl.

${ }^{1}$ Zob. np. Danuta Wajsprych, Pedagogia agatologiczna. Studium hermeneutyczno-krytyczne projektu etycznego Józefa Tischnera (Toruń-Olsztyn: Wydawnictwo Naukowe Uniwersytetu Mikołaja Kopernika, 2011).

2 Zob. np. Paweł Walczak, Wychowanie jako spotkanie. Józefa Tischnera filozofia człowieka jako źródło inspiracji pedagogicznych (Kraków: Impuls, 2007). 
resowaniem pedagogiki, by szukać filozoficznych uzasadnień dla podejmowanej działalności pedagogicznej. Drugi ściślej odpowiada na ewentualne zapotrzebowanie filozofii, by rozeznać się, jak refleksja pedagogiczna integruje się z koncepcją filozoficzną autora Myślenia wedlug wartości oraz co do niej wnosi. Czy zatem pedagogia Tischnera jest konsekwentną aplikacją jego filozofii wolności, czy może tę filozofię poszerza i uzupełnia o aspekt niewidoczny z perspektywy samej filozofii, a doświetlony dopiero dzięki dodaniu doń perspektywy pedagogicznej?

Skonfrontowanie myślenia filozoficznego Tischnera, nierzadko bardzo abstrakcyjnego, z jego poglądami i przemyśleniami pedagogicznymi, tak dotykalnymi i bliskimi praktyce życia, może się okazać ciekawym badaniem i nieoczywistym co do jego rezultatów. Autorka świadomie rezygnuje z formułowania hipotez, ponieważ lepiej to oddaje jej wstępne nastawienie - wynikające z niewiedzy i chęci lepszego zrozumienia filozoficzności myśli pedagogicznej i pedagogicznego wymiaru myśli filozoficznej Tischnera. Ten sposób analizy - gdy nie opuszczamy pola filozoficznych rozważań, ale przedmiotowo trzymamy się wychowania i nauczania, a więc domeny pedagogiki - proponuję tu zastosować. Umożliwi nam to sam Józef Tischner, który w takiej podwójnej roli często występował zarówno w życiu, jak i w swych tekstach. Był i filozofem, i pedagogiem. Pomocne będą też świadectwa i wspomnienia, po które sięgnęłam, odwiedzając w tym celu Łopuszną, rodzinną miejscowość, z którą był szczególnie związany i która przechowuje liczne pamiątki i ślady obecności sławnego w świecie łopusznianina. Miejsce, które oddziałaływało na niego i które zwrotnie też jakby kultywuje coś z jego wypracowanej praktycznej filozofii życia. Czy powstałaby filozofia i pedagogia Tischnera bez tych miejsc? Na ile są to opisy rzeczywistości wzajemnie ze sobą powiązane? Wstępna orientacja w tekstach Tischnera pozwala wnosić, że nie mamy tu do czynienia z prywatną pedagogią wypowiadaną przez filozofa, ale raczej z filozofią wychowania. Ale aby się o tym przekonać, proponuję poprowadzić analizę zagadnienia w następującym porządku.

Na początek spróbuję wydestylować z całości twórczości Tischnera te wątki, dotyczące wychowania i nauczania, których nie dałoby się odczytać z samej jego filozofii. Przydatne tu będą głównie wspomnienia i wywiady na temat praktyki wychowawczej przebiegającej w rodzinie, szkole, kościele, dostępne w tekstach publikowanych, ale także zaczerpnięte z rodzinnej miejscowości, Łopusznej, która przechowuje wiele pamiątek związanych z jego życiem i twórczością (np. z „Tischnerówki”, czyli z Domu Pamięci ks. prof. Józefa Tischnera). Następnie przejdę do omówienia kluczowych tekstów, 
tworzących jego myśl pedagogiczną, w których znajdujemy opis i definicje pojęcia wychowania, opis jego istoty oraz przeciwieństw $\mathrm{w}$ formach pseudowychowania, a także jego relacji do nauczania. Sam Tischner przyznaje, że u podstaw każdej teorii i praktyki pedagogicznej leży jakaś koncepcja człowieka ${ }^{3}$. Wiadomo, jak duży obszar inspiracji dla pedagogiki stanowi filozofia, w tym autora Sporu o istnienie człowieka. Poniższe opracowanie przyjmuje jednak inny kierunek analizy. Przez wgląd w pedagogiczne myślenie chcę tą drogą odtworzyć szersze filozoficzne tło, w które wpisuje się doświadczenie wychowania. Ten kierunek wyznaczony jest stawianym tu pytaniem o to, co pedagogiczne myślenie Tischnera wnosi do jego filozofii. Może się bowiem okazać, że wgląd w poglądy pedagogiczne pozwoli zniuansować niektóre jego filozoficzne pojęcia - dzięki ich powiązaniu z doświadczeniem pedagogicznym. A może praktyka pedagogiczna pozwoliła Tischnerowi na ujawnienie części jego filozoficznych poglądów?

Jest to więc zapowiedź kolejnego kroku, w którym poddam interpretacji pedagogię Tischnera w powiązaniu z jego filozofią. Szczególnie będę tu mieć na uwadze wolność jako stały punkt myślenia Tischnera. Nie da się więc pominąć zbadania miejsca wolności w przestrzeni wychowania. A więc wychowanie w relacji do wolności, i na odwrót: wolność a wychowanie, będąc ze sobą powiązane, generują pytanie, $w$ jakim stopniu jest to koncepcja wychowania w wolności, a w jakim wychowania do wolności. A może jedno i drugie? Na ile w poglądach pedagogicznych objawia się jego zainteresowanie wolnością, na ile sama wolność zostaje lepiej zrozumiana w powiązaniu z wychowaniem i czy pedagogiczne myślenie nie dodało czegoś do jego rozumienia wolności? Odpowiedź na ostatnie pytanie będzie wiązała się już z przejściem do ostatniej części tekstu, to jest podsumowania. O ile uda mi się zaprezentowanie Tichnerowskiej fenomenologii wychowania, będę chciała spointować całość rozważań próbą wykazania wkładu myślenia pedagogicznego Tischnera do jego filozofii wolności.

\section{Dialogi o wychowaniu na tle krajobrazu spod Turbacza}

„Świat stoi naopak. Nie jest dobrze, ale żeby miało być tak cołkiem źle, to tego nie powiym" - ten napis widnieje przed odnowioną szkołą w Łopusznej. Są to słowa Tischnera - wychowanka szkoły, jak głosi podpis. Ze 1334.

3 Zob. Józef Tischner, „Z problematyki wychowania chrześcijańskiego”, Znak 11 (1966): 
szkołą w Łopusznej od samego prawie początku byli związani oboje rodzice Tischnera. W 1932 roku jego ojciec Józef został jej kierownikiem, piastując tę funkcję aż do 1970 roku, natomiast matka Weronika była w szkole nauczycielką. Rodzina Tischnerów mieszkała w budynku szkoły. Z pewnością wywarło to wpływ na syna, o czym będzie więcej mówił w rozmowie spisanej w książce Przekonać Pana Boga. Poza nauczycielskim klimatem domu jego dzieciństwo i dorastanie wypełniały góry. „Dopiero po wielu latach chodzenia po górach i bycia w nich - wspomina w rozmowie z Anną Karoń-Ostrowską prezentowanej w książce Spotkanie - zrodziła się we mnie pewna filozofia przestrzeni. Dostrzegłem, że poprzez przestrzeń wyraża się idea wolności człowieka. Myśl tę można wyrazić prosto: jaka jest twoja przestrzeń, taka jest twoja wolność" ". Po latach spędzonych w świecie akademickim postawił - na drodze na Turbacz - bacówkę, by móc powrócić „do korzeni, do krajobrazów dzieciństwa, a przede wszystkim do ludzi, wśród których wyrastał. Był tam - pisze Wojciech Bonowicz - pod każdym względem u siebie"s. Przestrzeń gór, w której się wychował i żył, zanim rozwinął swoją filozofię, współtworzyła jego krajobraz fundamentalny. „Myślenie nigdy nie może przekroczyć granic pewnego krajobrazu, który nosi człowiek pod powiekami. Zawdzięcza go człowiek domowi, z którego wyrosła jego dusza, oraz przeszłości, która podsuwała mu obrazy bohaterów. W ten sposób człowiek kształtuje siebie”. „Mój krajobraz fundamentalny bierze się z gór i trochę z szumu Dunajca... Natomiast horyzont religijny z tych drewnianych kościółków, wśród których wyrastałem - z kościółka w Jurgowie, z kościółka w Łopusznej"”.

$\mathrm{W}$ tej scenerii domu i gór trzeba jeszcze wyodrębnić miejsce na wątek spotkania z drugim człowiekiem. Z pozoru wydaje się ono - mówi Tischner - ,wydarzeniem przypadkowym: nie wiadomo, kiedy, gdzie i dlaczego... Gdy jednak nastąpi, okazuje się, że było przygotowane przez całą przeszłość osób, które się spotkały. Widać wówczas, jak istotną rolę we wzajemnym naprzeciw siebie odgrywa to, co ci ludzie mają już za sobą"”. „Spotkanie to najgłębsze i najbardziej bogate z doświadczeń, jakie człowiek może w swo-

${ }^{4}$ Spotkanie. Z ks. Tischnerem rozmawia Anna Karoń-Ostrowska (Kraków: Wydawnictwo Znak, 2008), 15-16.

${ }^{5}$ Wojciech Bonowicz, Tischner (Kraków: Wydawnictwo Znak, 2001), 281.

${ }^{6}$ Bonowicz, Tischner, 280.

7 Ten cytat zaczerpnęłam z jednej z tablic pamiątkowych przy kościele parafialnym w Łopusznej.

8 Józef Tischner, Filozofia dramatu (Kraków: Wydawnictwo Znak, 2006), 13. 
im życiu przeżyć. Kto nie spotkał na swojej drodze człowieka, ten, można powiedzieć, zmarnował swoje życie" ". Jeden z mieszkańców Łopusznej, zaprzyjaźniony z nim Wawrzyniec Kuchta, wypowie się o Tischnerze, że był on „prawą ręką człowieka”, a Wojciech Bonowicz doda, że choć wracając do Łopusznej, cenił sobie ciszę bacówki, w której dużo pracował, to jeszcze bardziej liczyły się dla niego „rozmowy z sąsiadami i szkolnymi kolegami, których spotykał w drodze do kościoła czy na przystanek autobusowy albo którzy przychodzili posiedzieć z nim na polanie"10.

Dopełnieniem tego krajobrazu niech będzie scena podczas drogi na Turbacz w pierwszą niedzielę sierpnia 1981 roku, gdy wspinając się wraz z mieszkańcami Łopusznej, Tischner zatrzymał się przy Polanie Rusnakowej, by odprawić mszę świętą. Wypowiedział przy tej okazji kilka słów o wolności i miejscu świętym.

Moi drodzy, kiedy się tutaj jest, to się widzi, co znaczy to słowo: «śleboda». Śleboda to jest coś różnego od swawoli. Swawola niszczy, swawola depcze. Nie patrzy: trawa, nie trawa, zboże, nie zboże... Swawola niszczy. Śleboda jest mądra. Śleboda umie po gospodarsku zadbać, po gospodarsku umie tę ziemię uprawić. Las chroni, żeby był lasem. A z człowieka ta śleboda potrafi wydobyć to, co w człowieku najlepsze ${ }^{11}$.

Idąc dalej w swych rozważaniach o wolności, stojąc na Polanie Rusnakowej, ks. Tischner zaakcentował też wagę miejsca, które oddziałuje na człowieka swoją świętością. „Miejsce święte to jest takie miejsce, gdzie człowiek usiłuje ze siebie wydobyć to, co najlepsze. Rozmaicie bywa, są rozmaite miejsca na świecie. Są takie miejsca, które pogarszają człowieka i takie, które polepszają. Miejsce święte to jest takie miejsce, gdzie człowiek wydobywa ze siebie to, co ma najlepsze, i chce to, co ma najlepsze, utrwalić" ${ }^{2}$. Te wybrane wypowiedzi Tischnera, które w części zaczerpnęłam z Łopusznej podczas moich wędrówek śladami tego filozofa, daje się interpretować jako przekaz wyraźnie pedagogiczny. Są w nich wskazania, jak żyć, czego się wystrzegać, co szanować, co inicjować, by życia nie marnować, lecz przeciwnie, nadawać mu sens, brać za nie odpowiedzialność i je kształtować.

\footnotetext{
9 To kolejny cytat zaczerpnięty z jednej z tablic pamiątkowych w Łopusznej.

10 Bonowicz, Tischner, 281.

11 Tamże, 344.

${ }^{12}$ I jeszcze jeden cytat zaczerpnięty z jednej z tablic pamiątkowych w Łopusznej.
} 


\section{Uznać niepowtarzalność, czyli rozmowa o wychowaniu i nauczaniu}

Chcąc z kolei zacząć wyławiać z bogatego zbioru tekstów i wypowiedzi Tischnera te poświęcone wychowaniu, warto zacząć od jednego z najpóźniejszych, a zawartego w rozmowie pod tytułem Przekonać Pana Boga, prowadzonej przez Tischnera z Dorotą Zańko i Jarosławem Gowinem w 1999 roku. Jest to wypowiedź w formacie zaplanowanym przez redaktorów, nie da się więc tu odszukać autorskiej konstrukcji filozoficznej wokół spraw wychowania, ale i tak tekst dostarcza wielu cennych przemyśleń pedagogicznych. Jako że rozmowa miała miejsce po ponad 30 latach po napisaniu dwóch pierwszych pedagogicznych tekstów, czyli „Z problematyki wychowania chrześcijańskiego" i „Z problematyki nauczania”, i prawie 20 lat po komentarzu na temat wychowania z czasów Solidarności zawartego w Etyce solidarności (do których nawiążę później), wypowiedzi bazują na dużym doświadczeniu i przemyśleniu spraw. Zatrzymując uwagę na tej rozmowie, Tischner odsłania fragmenty swojego życia rodzinnego i wychowania, opisuje czasy dzieciństwa i miejsca, w których wzrastał, czasy szkolne, w których pobierał naukę; wypowiada się o wpływie nań rodziców, nauczycieli, duszpasterzy oraz rówieśników. Jest to bardzo cenna wiedza biograficzna, ale zarazem wgląd w poglądy na wychowanie i nauczanie, które przy okazji są przez niego wypowiedziane.

Tischner osobiście docenia, że był wychowywany do wypełniania obowiązków, że w domu obowiązywały zasady, których trzeba było przestrzegać, a przy tym, że wiedza i książki były wysoko cenione i dostępne. Zwraca jednak uwagę dbałość, z jaką stara się uwzględniać w opisie wychowania perspektywę dziecka, a co za tym idzie, uznawać jego indywidualność i niepowtarzalność, liczyć się z jego potrzebami i predyspozycjami, pozwolić mu być sobą. Tischner pedagog przekonuje, że dziecko ma wrodzony zmysł sprawiedliwości i poczucie godności, pragnie uznania oraz szacunku. Przejawia potrzebę samodzielności i swobody. Powinno więc być w swej jednostkowości dowartościowane, czyli uznane i doświadczające miłości rodzicielskiej, a jednocześnie stawiane wobec zadań, wymagających zdyscyplinowania i poświęcenia. Powinno się je uczyć „umiejętności przewidywania i myślenia, oglądania skutków swoich poczynań" ${ }^{13}$, by korzystając z samo-

13 Przekonać Pana Boga. Z ks. Józefem Tischnerem rozmawiają Dorota Zańko i Jarosław Gowin (Kraków: Wydawnictwo Znak, 1999), 138. 
dzielności, uczyły się roztropności. Tischner podkreśla też wagę rozbudzania wielostronności, czyli „umiejętności myślenia i patrzenia na każdą sprawę z wielu stron" ${ }^{14}$, która chroni na przykład przed okrucieństwem, od którego dzieci nie są wolne. Jak to ujmie, naturze trzeba „rozumnie pomagać”, a więc kształtując charakter dziecka, „nie łamać, ale cierpliwie pielęgnować, odwołując się do tego, co w dziecku dobre"15.

Te pedagogiczne wskazania Tischner kieruje do rodziców jako pierwszych wychowawców, z kolei wobec szkoły ma trochę inne oczekiwania. Jak podkreśla, „pierwszym zadaniem szkoły jest uczyć, nie wychowywać”, w szkole „wychowuje się poprzez uczenie”16. Ale naukę, jak już to było powiedziane, pojmował Tischner nie tyle jako obowiązek, ale jako czas dany na doskonalenie siebie, w związku z czym nauczyciel jako wychowawca powinien przede wszystkim ,uczyć bezinteresownego podejścia do przedmiotu" ${ }^{17}$. Co ciekawe, podobnie jak to było w przypadku wychowania w rodzinie, opisując szkołę, znów przyjmuje perspektywę dziecka, którego pierwotnym podejściem do świata jest właśnie bezinteresowność. Chodzi więc o to, by tej postawy nie zatracić, ale na niej bazować i zaciekawić daną dyscypliną wiedzy, jej osiągnięciami, twórcami i bohaterami. Chciałby, aby tą drogą kroczył nauczyciel, budując osobowość ucznia, by przede wszystkim czuł się przed nim odpowiedzialny (a nie przed dyrektorem czy rodzicami). Większą więc wagę w dziele pedagogicznym Tischner przypisuje dobremu nauczycielowi niż dobremu wychowawcy. Fundament aksjologiczny szkoły i oparty na nim jej program wychowawczy chciałby konsekwentnie budować na prawach człowieka, cnotach obywatelskich, samorządzie i szacunku dla człowieka jako twórcy kultury. Widzi w tym sposób na radzenie sobie z nacjonalizmem jako błędnym programem wychowawczym szkoły, który absolutyzuje polskość. Tischner przeciwnie, wskazuje na człowieczeństwo jako wartość nienaruszalną, jemu podporządkowując polskość: „Polskość jest drogą do człowieczeństwa, a nie odwrotnie"18.

Jeszcze inne aspekty myślenia pedagogicznego odsłania fragment rozmowy poświęcony wychowaniu religijnemu czy szerzej Kościołowi. W tym miejscu Tischner może czerpać z bardzo bogatego doświadczenia najpierw zdobywania własnej formacji w seminarium, gdzie jak przyzna, nie czuł się

\footnotetext{
14 Tamże, 134.

15 Tamże, 133.

16 Tamże, 145.

17 Tamże.

18 Tamże.
} 
podmiotem, potem wykładowcy i duszpasterza, księdza, głoszącego kazania dla niemal wszystkich grup społecznych, łącznie z przedszkolakami. Jest to refleksja, w której najwyraźniej zaznaczają się przemyślenia, które zawarł przed laty w swoich podstawowych tekstach pedagogicznych. W tym miejscu podkreśliłabym kilka wątków, wyróżniających właśnie to ujęcie. Tischner nie zmienia konwencji wypowiedzi, a więc na pytania, jak budować więź dziecka ze wspólnotą kościelną, jak je wprowadzać w świat wiary i przyzwyczajać do liturgii, odpowiada, że głównym celem wychowania religijnego jest „wtajemniczenie w Ewangelię”, które „pozwala dopracować się świadomości ludzkiej wartości”, zgodnie ze słowami: „Cenniejsi jesteście niż wróble" ${ }^{19}$. Chodzi więc o to, by dzieci wciągnąć w liturgię, sprawić, by były słyszane, potrzebne i czuły się w Kościele u siebie, a jednocześnie, by miały poczucie uczestniczenia w symbolice i tajemnicy wiary. Przekazanie wiary wykracza poza możliwości księdza, ale pozostaje budowanie relacji powiernictwa. „Tropem wychowania musi się stać idea wyzwolenia”. Oznacza to, że wolność przez powiązanie z prawdą Ewangelii - przekonuje Tischner - jest powolnym wychodzeniem $\mathrm{z}$ różnych zniewoleń i jest jak „roślina, która powoli wydobywa się z ziemi, kwitnie i owocuje”20. W wymiarze religijnym pokładanie przez dziecko swojej nadziei w wychowawcy jest zarazem drogą budowania relacji z Bogiem jako instancją odwoławczą, na której się można oprzeć ${ }^{21}$. Nie można tej nadziei zawieść. Wychowawca, który odbiera nadzieję, jest beznadziejnym wychowawcą w podwójnym sensie, jako człowiek i jako ten, w którym ma być obecny Bóg ${ }^{22}$. Droga do Boga wiedzie przez spotkanie z człowiekiem ${ }^{23}$.

Podsumowując tę część prezentacji poglądów pedagogicznych Tischnera, mocno związanych z praktyką czy wręcz wywołanych pytaniami o konkretne rady i sugestie wychowawcze, wskazałabym na wybijające się na pierwszy plan głęboko humanistyczne podejście antropologiczne ich autora. Sprawia ono, że na pierwszym planie sceny pedagogicznej jest stale obecny jej podmiot - dziecko, wychowanek i uczeń, o którego wzrost i uznanie

19 Tamże, 157.

20 Tamże, 161.

21 Tamże, 165.

${ }^{22}$ Tamże, 166. Por. Jacek Filek, Filozofia jako etyka (Kraków: Wydawnictwo Znak, 2001), 107-108, 119-120.

${ }^{23}$ Por. Katarzyna Wrońska, „Człowiek w doświadczeniu wielowymiarowej transcendencji”, w: Antropologiczna pedagogika ogólna, red. Marian Nowak, Piotr Magier, Iwona Szewczak (Lublin: Wydawnictwo KUL i Wydawnictwo GAUDIUM, 2010), 181-183. 
niepowtarzalności ma zadbać jego środowisko życia i wychowania, a więc rodzina, szkoła i Kościół. Tischner w jednym z wywiadów deklarował, że czuł się wpierw filozofem, potem księdzem, a nad obiema dystynkcjami górowało człowieczeństwo ${ }^{24}$. Przechodząc dalej, czyli do tekstów filozoficznych poświęconych wychowaniu i nauczaniu, przedmiotowi pedagogiki, należy zaznaczyć, że Tischner zagłębia się w temat, pytając o istotę tych procesów. Podstawa antropologiczna pozostaje, ale zostaje poszerzona o wymiar aksjologiczny, w tym etyczny.

\section{Pytanie o istotę wychowania - wprowadzenie do fenomenologii wychowania}

Jedno z pierwszych pogłębionych filozoficznych ujęć wychowania znajduje się w tekście „Z problematyki nauczania” z 1968 roku. Jest tam mowa o dwóch funkcjach, które ma do spełnienia nauczyciel, mianowicie: nauczycielskiej i wychowawczej. W tym tekście widoczna jest prezentacja wychowania na tle nauczania bądź w powiązaniu z nim. Dwa lata wcześniejszy tekst poświęcony wychowaniu, „Z problematyki wychowania chrześcijańskiego”, Tischner pisze znów z perspektywy porównawczej, tym razem krzyżując wychowanie z pseudowychowaniem. Trzecim ujęciem wychowania jest krótki „komentarz filozoficzny” - jak to nazwał filozof - pisany „W marszu”, który znalazł się obok kilkunastu innych, poświęconych między innymi takim sprawom, jak: wspólnota, praca, nauka, demokracja, rodzina, ojczyzna, wywołanych wydarzeniami roku 1980 i pod wpływem rodzącego się ruchu Solidarności w zbiorze Etyka solidarności. Tu też autor korzysta z metody prezentacji wychowania nie wprost, ale - jak to ujmuje - z perspektywy pozoru wychowania.

Te trzy ujęcia znów mają ze sobą coś wspólnego, podobnie jak to było we wcześniejszej antropologicznej odsłonie sceny pedagogicznej. Wychowanie jest tu opisywane drogą okrężną, niejako w krzywym zwierciadle. Można sądzić, że w ten sposób Tischner - wychodząc od karykatury wychowania - chce wyłuskać, doszukać się istoty wychowania, dojść do tej jego postaci, którą powinno być, a nie jest. W pierwszym tę normatywność wychowania udaje mu się pokazać w świetle pojęcia prawdy, w drugim - w per-

${ }^{24}$ Na podstawie materiałów audiowizualnych w Domu Pamięci ks. prof. Józefa Tischnera, „Tischnerówki” w Łopusznej. 
spektywie założeń chrześcijaństwa, w trzecim - w ciągu spraw publicznych, wymagających etycznego naświetlenia, uzasadnienia i dowartościowania, które nazwie zbiorczo Etyka solidarności. A jeśli tak, to może to wskazywać na przejawianie się w tym miejscu stałej cechy filozofii Tischnera. Jest ona wyraźnie opisana w tekście Myślenie według wartości. Autor argumentuje, że w naszym myśleniu najpierw objawia się poziom agatologii, czyli niezgody na coś, dopiero później dołącza poziom aksjologii, czyli kreślenia tego, jak być powinno ${ }^{25}$. Jeśli to przenieść na grunt jego refleksji filozoficznej o wychowaniu i nauczaniu - na poziomie agatologii u Tischnera pojawia się opis pseudowychowania - czym wychowanie nie powinno być, a jak się prezentuje i wzbudza krytykę oraz niezgodę.

Na dalszym etapie - już na poziomie aksjologii - Tischner wypracowuje ujęcie wychowania w jego istocie i do tego potrzebuje konkretnych wartości, w świetle których wychowanie występuje, takich jak: wolność, godność, nadzieja, prawda. W powiązaniu z tymi wartościami samo wychowanie objawia swoją naturę preferencji: chodzi o coś ważnego, i o kogoś. Tam, gdzie wychowanie zostaje połączone $\mathrm{z}$ wartościami, Tischner pisze albo wprost o istocie wychowania, albo o wychowaniu do wolności przez wolność, do prawdy przez prawdę... i tak dalej. Można wnosić, że tą drogą - nie wprost w świetle wartości także udaje mu się odsłonić sens wychowania. Sam to przyznał, pisząc, że jeśli się myśli o wychowaniu, to zawsze dotyka się też zagadnienia wartości. Zawsze bowiem

w wychowaniu dokonuje się wyboru według przyjętej z góry hierarchii wartości czy to osobistych walorów wychowanka, które zamierza się rozwijać, czy to społeczeństwa, do którego zamierza się je przystosowywać [...] jest ono czynnością zaszczepiania wychowankowi określonej hierarchii wartości głównie etycznych. Bez aksjologii nie ma wychowania, choć wychowanie nie kończy się zapewne na aksjologii ${ }^{26}$.

Jakie opisy wychowania da się odnaleźć w tych trzech tekstach? W pierwszym z nich wychowanie pojawia się niejako jako druga strona nauczania. Bardzo cenne okazuje się u Tischnera ukazywanie nauczania i wychowania jako integralnej całości, za którą odpowiedzialny jest nauczyciel. Wychowawcza funkcja ,jest następstwem powiązania między nim [nauczycielem - K. W.]

25 Józef Tischner, Myślenie według wartości (Kraków: Wydawnictwo Znak, 2002), 483-491.

${ }^{26}$ Józef Tischner, „Z problematyki nauczania”, Znak 7/8 (1968): 912. 
a drugim człowiekiem będącym w stanie wewnętrznego dojrzewania, wzrostu”"27. Samo zaś wychowanie, jak to ujął, ,polega na przekazywaniu uczniom pewnych wartości, w szczególności wartości etycznych, oraz umiejętności podejmowania decyzji zgodnie z nimi"28. Parę stron dalej wypowie się w podobnym tonie:

wychowanie polega przede wszystkim na zaszczepieniu wychowankowi autentycznej hierarchii wartości tak, aby wyższe wartości uznawał on za wyższe, a niższe za niższe. Polega ono także na tym, aby obudzić w wychowanku szczególne uczulenie na wartości obowiązujące powszechnie, tzn. obowiązujące każdego człowieka. Im bardziej szczegółowa jest wartość, tym mniejsze pole do popisu ma wychowawca. W przypadku takich wartości jak miłość do konkretnej osoby, jak poświęcenie się np. malarstwu, powołanie do stanu duchownego - pisze Tischner - wychowawca powinien przede wszystkim milczeć. Wyboru będzie dokonywał sam wychowanek ${ }^{29}$.

Kilka akapitów dalej wskaże jeszcze inne sytuacje, w których wychowawca powinien milczeć. Będą się one wiązały z powołaniem nauczyciela, by być w zgodzie z prawdą i głosić w pierwszej kolejności prawdę naukową. „Gdy milczy nauczyciel - powie - wychowawca musi przestać działać" ${ }^{30}$. W tym miejscu warto podkreślić, że pomimo wyróżniania przez Tischnera pozycji nauczyciela wychowawca stale jest w tej sytuacji obecny. O ile nauczyciel obowiązany jest realizować w nauczaniu przede wszystkim prawdę, to zadaniem wychowawcy jest znaleźć odpowiedni moment dla przekazania danej prawdy, tak by okazało się to owocne i dobrze zrozumiane ${ }^{31}$.

Tekst „Z problematyki wychowania chrześcijańskiego” - poza przypomnieniem zasad chrześcijańskich, które mają być podstawą pedagogiki chrześcijańskiej - dostarcza opisu trzech postaci pseudowychowania: mechanizmu, legalizmu i totalizmu wychowawczego. Każda z nich jest prezentacją wychowania w krzywym zwierciadle. Tischner ocenia praktykę pedagogiczną, z którą stykał się w środowisku kapłańskim. Jakim był pedagogiem podczas spełniania posługi kapłańskiej, można się przekonać, czytając na przykład jego kazania dla dzieci przedszkolnych. Podczas mszy dla dzieci

\footnotetext{
27 Tamże, 903.

28 Tamże, 904.

29 Tamże, 912.

30 Tamże.

31 Tamże, 913.
} 
Tischner nie tyle głosił kazanie, ile prowadził z dziećmi rozmowę, na przykład o przebaczeniu czy o przyjaźni, podczas której poszczególne dzieci, do których ksiądz zwracał się po imieniu, zabierały głos, przynosiły na msze swoje misie, czuły się w Kościele św. Marka u siebie, a jednocześnie były wprowadzane w tajemnice Eucharystii ${ }^{32}$.

Wracając do karykatury wychowania, należy zaznaczyć, że u podstaw każdego z pseudosu, według Tischnera, leży lęk przed wolnością, źródło „wszelkiego totalizmu” ${ }^{33}$. Daje temu wyraz wychowanie, które przyjmuje postać wyrabiania w wychowankach dobrych przyzwyczajeń (mechanizm wychowawczy) bądź kształtowania postawy posłuszeństwa wobec prawa (legalizm wychowawczy), wychowawcy zaś nadaje miano osoby godnej naśladowania (totalizm wychowawczy). Dla Tischnera wszystkie te sytuacje obnażają pozór, fałsz i roszczenie niczym nieuzasadnione, a podszyte niewiarą w ludzką wolność. „Wychowanie zakłada wolność”34 - jak powie w Etyce solidarności - a wraz z nią ryzyko co do rezultatów wychowania; te będą prawdopodobne, a nie pewne ${ }^{35}$. Pedagogika totalistyczna stawia na pewność - uzyskaną siłą wytrenowanych w wychowanku przyzwyczajeń, posłuszeństwa normom oraz autorytarnej postawy nauczyciela-wychowawcy, pilnującego pozycji wzoru do naśladowania. Tischner widzi paralelę między totalistycznym nauczycielem-wychowawcą a totalistyczną władzą państwową.

\section{Wychowanie do wolności przez wolność}

Co to oznacza „wychowanie do wolności przez wolność”? To, że na poziomie agatologii, a więc tego, jak jest w wychowaniu, choć być nie powinno, widać, czym ono winno być. Brak wolności w różnych tego przejawach w przestrzeni wychowania: mechanizmu, legalizmu i totalizmu, odsłania jego postulowaną, preferowaną postać jako wychowania do wolności. Ale dokona się ono przez wolność. By rozwinąć szerzej wzajemne związanie wychowania $\mathrm{z}$ wolnością, wrócę jeszcze raz do wspomnień Tischnera z jego czasów dzieciństwa i dorastania. W tej osobistej perspektywie daje się

${ }^{32}$ Zob. Józef Tischner, Rozmowy z dziećmi. Kazania niecodzienne (Kraków: Znak, 2010), 22-31, 52-61.

33 Tischner, „Z problematyki wychowania”, 1338.

34 Józef Tischner, Etyka solidarności (Kraków: Znak, 2000), 89.

35 Zob. Tischner, „Z problematyki wychowania”, 1340. 
zauważyć, że jest to okres reglamentacji wolności, pochodzącej nie tylko z wymagań życia rodzinnego i obowiązków nakładanych przez rodziców i nauczycieli, ale bardzo wyraźnie wiążącej się z ustrojem polityczno-gospodarczym. Tischner rósł w czasach, w których wolność była stale zagrożona, najpierw przez okupanta, później przez ustrój i władzę komunistyczną. Po zmianie systemu władzy droga do wolności też okazywała się problematyczna i nie było zgoła łatwą sprawą wprowadzanie ram prawnych i standardów życia oraz gospodarowania w nowym państwie demokratycznym i liberalnym. Wśród wielu przeszkód była także ta tkwiąca w mentalności i strategii przetrwania wypracowanej w czasach reżimu, którą Tischner częstokroć przywoływał i opisywał jako homo sovieticus.

Na tę perspektywę doświadczania przez Polaków i samego Tischnera deficytu wolności można nałożyć dodatkowo tę, która wiąże się z prywatnym wymiarem życia rodzinnego i dorastania w nim dziecka. Zależność od rodziców, obowiązki, które dorośli nakładają na dzieci, to przebieg życia dziecka, w którym doświadcza ono braku wolności. Sam Tischner przyznaje, że zdarzało mu się w dzieciństwie uciekać od tych nakazów i zakazów, by być bliżej własnych pasji i zainteresowań. Był to jednak konflikt niejako dwóch różnych preferencji, dziecka i dorosłego, z konsekwencjami, które naturalnie musiały nastąpić po niewypełnieniu uzasadnionego nakazu dorosłych. Nieuzasadniony (obiektywną potrzebą) nakaz, a więc czysty rozkaz skierowany w stronę dziecka (uzurpacja woli dorosłego), to wyraz wychowania autorytarnego, najczęściej zarazem totalistycznego (czyli pilnującego pozycji człowieka godnego szacunku i naśladowania). Dorastanie w takim klimacie można uznać za pierwsze zetknięcie się z totalną władzą już w sferze prywatnej. Wiemy - także z wypowiedzi Tischnera - że pod tym względem rodzinne środowisko życia i wychowania Tischnera było wolne od władzy totalnej, natomiast środowisko szkolne i seminaryjne przyniosło mu już jej przykłady - które opisze między innymi w tekście „Z problematyki wychowania chrześcijańskiego". W przestrzeni szkolnej i seminaryjnej kontakt z nauczycielem totalistycznym jest kolejnym doświadczeniem władzy totalnej wciąż na przedpolu polityki. Pomimo to drogą życia, którą zdecyduje się wybrać, będzie kapłaństwo, pozwalające w tamtych czasach - totalitarnej władzy komunistycznej - w jego ocenie zachować wolnośćc ${ }^{36}$.

Na podstawie zaprezentowanej tu myśli Tischnera na temat wychowania i nauczania oraz wolności można wnosić, że da się u niego rozróżnić dwa

${ }^{36}$ Na podstawie materiałów audiowizualnych w Domu Pamięci ks. prof. Józefa Tischnera, „Tischnerówki” w Łopusznej. 
rodzaje braku wolności; jeden wynikający z konieczności i niedostatków natury i drugi, jako czysta uzurpacja czyjejś woli, często podszyta lękiem, a zarazem chlubiąca się i strzegąca pozycji wzoru do naśladowania, która daje sobie prawo odebrania wolności drugiej osobie. Tylko w tym drugim przypadku brak wolności wpisywałby się wyraźnie w zagadnienie drogi od totalitaryzmu do wolności. W pierwszym zaś przypadku dotykamy braku wolności, będącego udziałem dziecka dorastającego w naturalnym dla niego środowisku w rodzinie, szkole, a wśród wierzących także w Kościele, w którym nakłada się na nie różne - uzasadnione - obowiązki i powinności.

Brak wolności w doświadczeniu dziecka, wypływający z podejmowania obowiązków i zadań zlecanych mu przez dorosłych, powinien się przeplatać ze swobodą i zostawieniem dziecku przestrzeni do zagospodarowania. Ta przestrzeń swobody, pod wpływem kształtującego i kształcącego działania pedagoga i równolegle $\mathrm{z}$ nim, będzie sukcesywnie przemieniać się w wolność, niejako rosnąć w dziecku wraz z nim, uczącym się odpowiedzialności za podejmowane działania. Tischner trafnie przyrównuje wolność do gospodarowania na swoim: „śleboda to jest coś takiego, co czuje gospodarz w swoim gospodarstwie" ${ }^{37}$. W innym wymiarze wolność obecna na scenie pedagogicznej to wolność cechująca pedagoga, od którego można się jej uczyć. Wyrażenie „wychowanie przez wolność do wolności” celnie tę dynamikę ujmuje. Jest w nim zawarty kierunek starań, by się wolności uczyć bądź ją odzyskiwać, jednak ucząc się jej, już się z niej przecież korzysta. Zakładając wolność w wychowaniu, na niej się opieramy i tworzymy całą scenę, na której spotykają się aktorzy, doświadczający i uczący się wolności.

Tischner, wytykając błędy pedagogiczne przede wszystkim w odniesieniu do wychowania chrześcijańskiego, a więc własnego otoczenia, które dobrze rozeznał, przysłużył się całej pedagogice. Korzystając z dorobku pedagogiki chrześcijańskiej wskazał przykłady zniewoleń i lęku przed wolnością, które mogą leżeć u podstaw różnorakich totalnych roszczeń pedagogiki w ogóle. Wojciech Bonowicz przytacza w biografii Tischnera ciekawy program naprawczy postulowany przez filozofa w odniesieniu do formacji księży katolickich w Polsce, pochodzący z roku 1974, oceniając, że tą pracą stał się on sumieniem polskiego chrześcijaństwa na długo przed wystąpieniami po zmianie ustrojowej ${ }^{38}$. Ów program zasadza się na naprawie trzech wymiarów tej formacji. Pierwszy dotyczy wychowania i powinien oznaczać pusznej.

${ }^{37}$ Cytat zaczerpnięty z jednej z tablic pamiątkowych przy kościele parafialnym w Ło-

${ }^{38}$ Bonowicz, Tischner, 279. 
rozchodzenie się w Kościele z pedagogiką negatywną, czyli zaprzeczaniem zasług wychowawczych przeciwników katolickiej doktryny; drugi wiąże się z kształceniem seminaryjnym, które opiera się na dyscyplinie, a powinno przerzucać ciężar na budowanie dialogu wewnętrznego, a więc na pomoc i wsłuchiwanie się w ludzkie nadzieje studentów kleryków; ostatni zaś wymiar to „białe plamy” chrześcijaństwa, czyli nieufność wobec współczesnych prądów filozoficznych i nurtów w kulturze ${ }^{39}$. Tischner przyznaje, że za wszystkimi trzema wymiarami spraw wymagających poprawy stoi „zasadnicza nieufność w stosunku do człowieka". Za nią zaś kryje się lęk przed wolnością. Z tej nieufności rodzi się „chrześcijaństwo bez ludzi”, bazujące na wierze w Boga ludzi, którzy się na sobie zawiedli ${ }^{40}$.

\section{Integracja wychowania i nauczania na scenie pedagogicznej}

Nauczyciel totalistyczny to w praktyce człowiek sprzeniewierzający się prawdzie; wychowawca totalistyczny - Tischner nazywa go też beznadziejnym - to człowiek, który odbiera nadzieję, zdradza wychowanka, który mu zawierzył. Nauczyciel w pedagogicznym myśleniu Tischnera gra rolę wiodącą, a więc jego wierność zasadzie głoszenia prawdy naukowej stoi ponad innymi racjami. To z tego powodu nauczyciel, nie tracąc nic z roli wychowawcy, ma dać pierwszeństwo nauczaniu zgodnemu z kryterium prawdy. Integracja wychowania i nauczania jest tu podtrzymana, z pierwszoplanowym danym nauczycielowi zadaniem zaproszenia ucznia do myślenia i z zadaniem przebudzenia do życia danym wychowawcy. Sama postawa pobożności nie wystarcza, by wychować religijnie. Trzeba jeszcze ze znawstwem zaprezentować podwaliny doktrynalne, filozoficzne i kulturowe danej religii, nie bojąc się zderzenia z krytyką ze strony studentów żyjących tu i teraz oraz czerpiących z wielu źródeł kulturowych. Wychowawca jest u Tischnera za nauczycielem w tym sensie, że w sytuacji nieumiejętności czy braku wystarczającej wiedzy, by wyjaśnić pytanie bądź wątpliwość stawianą przez ucznia, trzeba się do tego przyznać, kosztem pozycji wzoru-autorytetu, jaką być może chciałoby się zajmować w relacji do ucznia. Dla Tischnera i tak liczy się najbardziej to pierwsze antropologiczne rozdanie, wedle którego

\footnotetext{
39 Tę słabość formacyjną kleryków wypomni także Jan Paweł II w encyklice Fides et ratio.

${ }^{40}$ Bonowicz, Tischner, 279.
} 
najpierw się jest człowiekiem, potem - parafrazując jego deklarację bycia najpierw człowiekiem, potem filozofem, na końcu kapłanem - jest się nauczycielem, a na końcu wychowawcą. ,Skoro wychowanek jest istotą wolną - mówi Tischner - zły pedagog nie jest znowu tak wielkim nieszczęściem, jakby się pozornie wydawało"41. Ta dystynkcja, niestety, często przegrywa w zderzeniu z konkretem, gdy stają naprzeciw siebie: zły pedagog i nieświadomy tego, bądź w poczuciu bycia zdradzonym przez „trującego”, niewiarygodnego wychowawcę-nauczyciela, wychowanek-uczeń.

\section{Droga od zniewolenia do wolności przez wychowanie - podsumowanie}

Wolność jest imieniem człowieka - ta antropologiczna zasada wniesiona do sytuacji wychowawczej oznacza, że ta ludzka praktyka nie może się bez niej udać. Jest nią przecież ,praca z człowiekiem i nad człowiekiem - z tym, kto znajduje się w stanie dojrzewania"42. Dlatego Tischner pisze, że „wychowanie zakłada wolność”, a „wychowanek jest istotą wolną"43. Równoczesne zderzenie $\mathrm{z}$ totalizmem w tej scenerii jest oznaką pseudosu w wychowaniu. Pedagogika totalistyczna to jedna z przeszkód wolności, odpowiednik totalitaryzmu politycznego na przedpolu polityki, to jest w sferze prywatnej i w obszarze edukacji. Tym, co broni scenę pedagogiczną przed totalizmem, jest głównie nauczycielskie powołanie bycia wiernym zasadzie prawdy naukowej, bez względu na to, jak bardzo by uwierała. Uczeń ma prawo wiedzieć i rozumieć. Dlatego myśl pedagogiczną Tischnera można umieszczać w obrębie filozofii edukacji. Przed totalizmem broni ją też pozycja wychowawcy, o ile gotowy jest przyjąć na siebie rolę powiernika nadziei, z którą zwraca się do niego wychowanek. Wychowanie jako praca z człowiekiem, budząca do życia i działania według własnego pomysłu, jako gospodarowanie na swoim, nie daje pewności, niesie ze sobą ryzyko porażki, złych wyborów życiowych wychowanka, ale jest to zarazem gwarancja jego humanistycznego fundamentu (odnawialnej nadziei i wierności). Nie nadaje się ono na wykorzystanie przez żadną władzę, która chciałaby „wychować sobie”, czyli urobić entuzjastę i poplecznika jej ideologicznego programu. Droga do

\footnotetext{
41 Tischner, „Z problematyki wychowania”, 1345.

42 Tischner, Etyka, 87.

43 Tischner, „Z problematyki wychowania”, 1345.
} 
wolności wiedzie więc przez wychowanie. Może to być jednak długa droga, jeśli obok totalnej zniewalającej władzy politycznej także przedpole polityki, a więc dom, szkoła czy Kościół, odpowiedzialne za wychowanie i nauczanie, będzie tworzyć jedynie pozór relacji pedagogicznej, okopując się na pozycji mechanizmu, legalizmu i totalizmu wychowania.

Wkład myślenia pedagogicznego Tischnera do jego filozofii wolności jest niebagatelny. Zakusy totalnej władzy zaczynają się - tak jak jej przeciwieństwo, czyli wolność - w sferze wychowania i nauczania. Co więcej, totalizm wychowawczy może się utrzymywać niezależnie od totalnej władzy rządzących, dlatego że lęk przed wolnością obywateli cechuje nie tylko część świata polityki. Przez wieki był też nastawieniem nieobcym hierarchom Kościoła katolickiego. Ważnego zwrotu dokonuje Sobór Watykański II, formułując nowy kierunek, w którym to człowiek staje się drogą Kościoła, a nie jak wcześniej, Kościół - drogą człowieka. Wiele z opisów Tischnera, w tym oba omawiane tu teksty pedagogiczne $\mathrm{z}$ lat sześćdziesiątych, przywołuje ten zwrot w myśleniu jako bardzo wyczekiwany, ale wprowadzany powoli i z oporami środowiska kościelnego. Również w szkole i w środowisku rodzinnym w poczuciu władzy rodzicielskiej i nauczycielskiej jeszcze niedawno sięgano do kar cielesnych i innych metod, godzących w godność dziecka, jako uprawnień pedagogicznych w rzędzie niekwestionowanych metod wychowawczych, egzekwujących brak podporządkowania się przez dzieci nakazom bądź zakazom dorosłych. Nieobcy jest też niejednemu z nas obrazek z życia szkolnego, gdy niekompetentny nauczyciel zastępuje brak wiedzy i lęk przed jego ujawnieniem bezwzględnością, autorytaryzmem i chłodem w relacjach z uczniami. Może więc być tak, że w sferze przedpolitycznej właśnie za sprawą wychowania i nauczania wciąż tli się totalizm, pomimo że w sferze politycznej dokonuje się zmiana w kierunku budowania struktur demokratycznych i państwa prawa. Totalizm wychowawczy może trwać niezależnie od politycznego, może też go wzmacniać postawami bierności i roszczeniowości, a tym samym hamować rozwój społeczeństwa obywatelskiego w państwie demokratycznym. Tischner w swoim myśleniu pedagogicznym - choć przestrzega przed totalistycznym wychowaniem - jednocześnie ufa, że wolność się wybroni, również za sprawą mądrych nauczycieli i wychowawców, którzy mają nadzieję i jako wolni ludzie będą chcieli przyjąc na siebie powiernictwo nadziei swoich uczniów i wychowanków. Dla wielu - także dla mnie - jednym z nich był Józef Tischner. 


\section{Education and Freedom. An Attempt of Insights into Józef Tischner's Pedagogical Thinking (Summary)}

The text written from the perspective of philosophical pedagogy is an attempt to understand the pedagogical thought of one of the philosophers of freedom - Józef Tischner. The author poses the task of extracting the meanings and sense present in Tischner's source texts and statements he gives to education and instruction. It serves two purposes. The first one responds to the needs of pedagogy, which seeks philosophical justifications for undertaken pedagogical activity. The second one is more closely related to the need of philosophy; it is about checking how the pedagogical reflection fits into the philosophical concept of the author of Thinking by values and what it brings to it. By specifying the second goal, the author wants to look for the answer to the question: is Tischner's pedagogy a consistent application of his philosophy of freedom, or does it extend this philosophy and supplement it with pedagogical aspect, invisible from the perspective of philosophy itself.

Keywords: education; instruction; freedom; totalistic pedagogy; entrustment.

\section{Wychowanie a wolność. Próba wglądu w myślenie pedagogiczne Józefa Tischnera (Streszczenie)}

Tekst pisany z perspektywy pedagogiki filozoficznej jest próbą wglądu w myślenie pedagogiczne jednego z filozofów wolności - Józefa Tischnera. Autorka stawia przed sobą zadanie wydobycia i odczytania ze źródłowych tekstów i wypowiedzi Tischnera znaczeń i sensu, jakie nadaje on wychowaniu i nauczaniu. Ma to służyć dwóm celom. Pierwszy z nich odpowiada na zapotrzebowanie pedagogiki, która szuka filozoficznych uzasadnień dla podejmowanej działalności pedagogicznej. Drugi cel ściślej wiąże się z zapotrzebowaniem filozofii; chodzi o sprawdzenie, w jaki sposób refleksja pedagogiczna wkomponowuje się w koncepcję filozoficzną autora Myślenia wedlug wartości oraz co do niej wnosi. Uściślając ten drugi cel, autorka chce szukać odpowiedzi na pytanie: czy pedagogia Tischnera jest konsekwentną aplikacją jego filozofii wolności, czy może tę filozofię poszerza i uzupełnia o aspekt pedagogiczny, niewidoczny z perspektywy samej filozofii? 
Slowa kluczowe: wychowanie; nauczanie; wolność; pedagogika totalistyczna; zawierzenie.

\section{Bibliografia}

Bonowicz, Wojciech. Tischner. Kraków: Wydawnictwo Znak, 2001.

Filek, Jacek. Filozofia jako etyka. Kraków: Wydawnictwo Znak, 2001.

Galarowicz, Jan. Ks. Józef Tischner. Kraków: Petrus, 2013.

Przekonać Pana Boga. Z ks. Józefem Tischnerem rozmawiają Dorota Zańko i Jarosław Gowin. Kraków: Wydawnictwo Znak, 1999.

Spotkanie. Z ks. Tischnerem rozmawia Anna Karoń-Ostrowska. Kraków: Wydawnictwo Znak, 2008.

Tischner, Józef. Etyka solidarności. Kraków: Wydawnictwo Znak, 2000.

Tischner, Józef. Filozofia dramatu. Kraków: Wydawnictwo Znak, 2006.

Tischner, Józef. Myślenie wedtug wartości. Kraków: Wydawnictwo Znak, 2002.

Tischner, Józef. Rozmowy z dziećmi. Kazania niecodzienne. Kraków: Wydawnictwo Znak, 2010.

Tischner, Józef. Świat ludzkiej nadziei. Kraków: Znak, 2000.

Tischner, Józef. „Z problematyki nauczania”. Znak 7/8 (1968): 903-913.

Tischner, Józef. „Z problematyki wychowania chrześcijańskiego”. Znak 11 (1966): 1335-1345.

Wajsprych, Danuta. Pedagogia agatologiczna. Studium hermeneutyczno-krytyczne projektu etycznego Józefa Tischnera. Toruń-Olsztyn: Wydawnictwo Naukowe Uniwersytetu Mikołaja Kopernika, 2011.

Walczak, Paweł. Wychowanie jako spotkanie. Józefa Tischnera filozofia człowieka jako źródło inspiracji pedagogicznych. Kraków: Impuls, 2007.

Wrońska, Katarzyna. „Człowiek w doświadczeniu wielowymiarowej transcendencji”. W: Antropologiczna pedagogika ogólna, red. Marian Nowak, Piotr Magier, Iwona Szewczak, 175-188. Lublin: Wydawnictwo KUL i Wydawnictwo GAUDIUM, 2010. 
